Kinetics of carboplatin-DNA binding in genomic DNA and bladder cancer cells as determined by accelerator mass spectrometry

Sang Soo Hah, Kristen M. Stivers, Ralph W. de Vere White, Paul T. Henderson

January 3, 2006

Chemical Research in Toxicology 
This document was prepared as an account of work sponsored by an agency of the United States Government. Neither the United States Government nor the University of California nor any of their employees, makes any warranty, express or implied, or assumes any legal liability or responsibility for the accuracy, completeness, or usefulness of any information, apparatus, product, or process disclosed, or represents that its use would not infringe privately owned rights. Reference herein to any specific commercial product, process, or service by trade name, trademark, manufacturer, or otherwise, does not necessarily constitute or imply its endorsement, recommendation, or favoring by the United States Government or the University of California. The views and opinions of authors expressed herein do not necessarily state or reflect those of the United States Government or the University of California, and shall not be used for advertising or product endorsement purposes. 


\title{
Kinetics of Carboplatin-DNA Binding in Genomic DNA and Bladder Cancer Cells as Determined by Accelerator Mass Spectrometry
}

\author{
Sang Soo Hah ${ }^{\dagger *}$, Kristen M. Stivers ${ }^{\dagger}$, Ralph W. de Vere White ${ }^{\S}$, and Paul T. Henderson ${ }^{\dagger *}$ \\ ${ }^{\dagger}$ Biosciences Directorate and Center for Accelerator Mass Spectrometry, Lawrence Livermore National \\ Laboratory, 7000 East Avenue, L-441, Livermore, CA 94551 \\ ${ }^{\S}$ Department of Urology, School of Medicine, University of California Davis, Sacramento, CA 95817 \\ *To whom correspondence should be addressed: Tel: (925) 423-2822 Fax: (925) 422-2099 E-mail: \\ hah2@1lnl.gov or henderson48@1lnl.gov
}




\title{
Kinetics of Carboplatin-DNA Binding in Genomic DNA and Bladder Cancer Cells As Determined by Accelerator Mass Spectrometry
}

\author{
Sang Soo Hah, ${ }^{*}, \dagger$ Kristen M. Stivers, ${ }^{\dagger}$ Ralph W. de Vere White ${ }^{\S}$ and Paul T. Henderson ${ }^{*}, \dagger$ \\ Biosciences Directorate and Center for Accelerator Mass Spectrometry, Lawrence Livermore National \\ Laboratory, 7000 East Avenue, L-441, Livermore, California 94551, and Department of Urology, \\ School of Medicine, University of California Davis, Sacramento, California 95817
}

Received March 14, 2006

\begin{abstract}
Cisplatin and carboplatin are platinum-based drugs that are widely used in cancer chemotherapy. The cytotoxicity of these drugs is mediated by platinum-DNA monoadducts and intra- and interstrand diadducts, which are formed following uptake of the drug into the nucleus of cells. The pharmacodynamics of carboplatin display fewer side effects than for cisplatin, albeit with less potency, which may be due to differences in rates of DNA adduct formation. We report the use of accelerator mass spectrometry (AMS), a sensitive detection method often used for radiocarbon quantitation, to measure both the kinetics of $\left[{ }^{14} \mathrm{C}\right]$ carboplatin-DNA adduct formation with genomic DNA and drug uptake and DNA binding in T24 human bladder cancer cells. Only carboplatin-DNA monoadducts contain radiocarbon in the platinated DNA, which allowed for calculation of kinetic rates and concentrations within the system. The percent of radiocarbon bound to salmon sperm DNA in the form of monoadducts was measured by AMS over $24 \mathrm{~h}$. Knowledge of both the starting concentration of the parent carboplatin and the concentration of radiocarbon in the DNA at a variety of time points allowed calculation of the rates of Pt-DNA monoadduct formation and conversion to toxic cross-links. Importantly, the rate of carboplatin-DNA monoadduct formation was approximately 100-fold slower than that reported for the more potent cisplatin analogue, which may explain the lower toxicity of carboplatin. T24 human bladder cancer cells were incubated with a subpharmacological dose of $\left[{ }^{14} \mathrm{C}\right]$ carboplatin, and the rate of accumulation of radiocarbon in the cells and nuclear DNA was measured by AMS. The lowest concentration of radiocarbon measured was approximately $1 \mathrm{amol} / 10 \mu \mathrm{g}$ of DNA. This sensitivity may allow the method to be used for clinical applications.
\end{abstract}

\section{Introduction}

The DNA-damaging compound cis-diammine(1,1-cyclobutyldicarboxylato)platinum(II) (carboplatin) is a widely used second-generation platinum anticancer drug (1-5). Carboplatin and cis-diamminedichloroplatinum(II) (cisplatin) are particularly effective in the treatment of testicular, ovarian, head, neck, and nonsmall cell lung cancer. Both drugs are used in combination drug therapy against a wide variety of cancers including bladder cancer. Carboplatin has approximately the same spectrum of activity as cisplatin, but reduced toxicity. For example, carboplatin does not cause appreciable loss of high-frequency hearing, nor does it display significant renal or neural toxicity $(1-5)$. These toxicity differences are likely attributable to the lower reactivity of carboplatin with nucleophiles, since the 1,1cyclobutanedicarboxylic acid (CBDCA) ligand is a poorer leaving group than chloride. There are only a few previous studies on CBDCA ring-opening reactions of carboplatin (68 ) that report the relative inertness of carboplatin to hydrolysis and chloride substitution. For example, the half-life of carboplatin in chloride-free phosphate buffer at $\mathrm{pH} 7$ and $37^{\circ} \mathrm{C}$ is $268 \mathrm{~h}$ compared with $24 \mathrm{~h}$ for cisplatin under identical conditions $(6-8)$. Both compounds predominantly interact with DNA at

* To whom correspondence should be addressed. Tel: (925) 423-2822. Fax: (925) 422-2099. E-mail: hah2@1lnl.gov (for S.S.H.) or henderson48@1lnl.gov (for P.T.H.).

Lawrence Livermore National Laboratory.

$\S$ University of California Davis. guanine and adenine nucleotides to form Pt-DNA monoadducts that frequently react with a second nucleotide to form Pt-DNA intra- and interstrand diadducts. The structure of the toxic diadduct is likely to be identical for both carboplatin and cisplatin, since they share the cis-diammine carrier ligands and differ only in the nature of the leaving groups $(1-5)$. The mechanism of action for cisplatin likely involves displacement of the chloride ligands by water to form two active species, cis- $\left[\mathrm{PtCl}\left(\mathrm{NH}_{3}\right)_{2}\left(\mathrm{OH}_{2}\right)\right]^{+}$and cis- $\left[\mathrm{Pt}\left(\mathrm{NH}_{3}\right)_{2}\left(\mathrm{OH}_{2}\right)_{2}\right]^{2+}$, that electrostatically and covalently bind to DNA (1-5). However, whether carboplatin functions as a prodrug or reacts with DNA without metabolic or chemical modification remains uncertain. While overall binding kinetics of carboplatin to DNA have been determined experimentally, there is no published analysis of individual binding rates that consider separately monoadduct and diadduct formation (6). However, the kinetics of carboplatin binding to 2'-deoxyguanosine monophosphate (dGMP) support a two-step consecutive irreversible pseudo-first-order mechanism (monoadduct followed by diadduct formation in the presence of a vast excess of dGMP) (7). This mechanism differs from that of cisplatin because the resulting DNA monoadducts are not likely aquated or chlorinated. Furthermore, measurement of Pt-DNA monoadduct levels in DNA has been controversial because of chemical instability of the adduct and the sensitivity limitations of conventional detection methods, such as inductively coupled plasma mass spectrometry (ICP-MS), atomic 
Scheme 1. Putative Reaction Mechanism of Carboplatin with DNA to Form Monoadducts and Diadducts (the Position of the ${ }^{14} \mathrm{C}$ Label in Carboplatin Used in the Study Is Asterisked) ${ }^{a}$

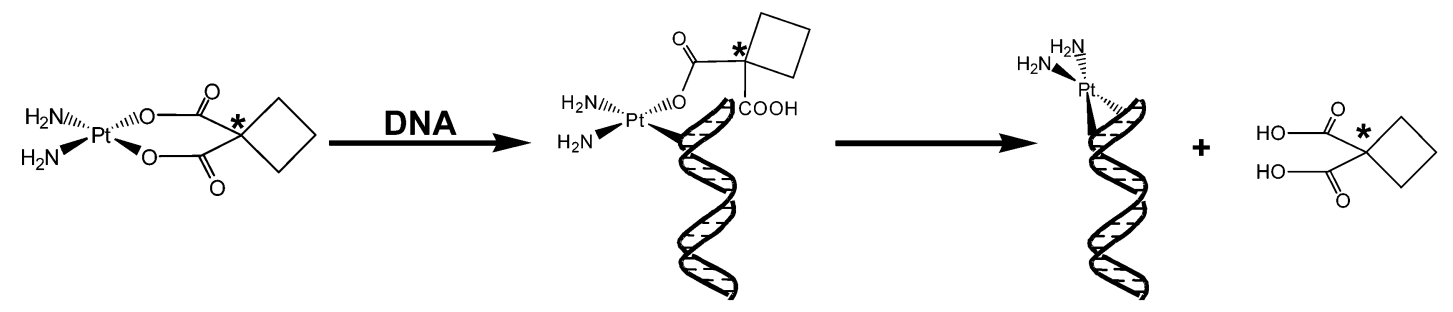

carboplatin $(\boldsymbol{A})$

Pt-DNA monoadduct $(B)$

Pt-DNA diadducts + CBDCA $(C)$

a A represents unreacted carboplatin, $\mathrm{B}$ is the carboplatin-DNA monoadduct, and $\mathrm{C}$ is the free 1,1-cyclobutanedicarboxylic acid (CBDCA) resulting from Pt-DNA diadduct formation and other types of nucleophilic displacement.

absorption spectrophotometry (AAS), and immunoassays (914).

Although platinum drug binding to purified DNA has been extensively characterized, measurement of the adducts in vivo with higher sensitivity and precision is desirable, because it remains unclear which of the $\mathrm{Pt}-\mathrm{DNA}$ adducts are responsible for the biological activity of platinum-based anticancer drugs. In particular, the kinetics of carboplatin mono- and diadduct formation in cells is undefined $(1-5)$.

We report the use of accelerator mass spectrometry (AMS) not only to determine the binding kinetics of carboplatin to genomic DNA, but also to monitor uptake and nuclear DNA binding of the compound in T24 human bladder cancer cells. AMS is a sensitive and precise technology for tracing ${ }^{14} \mathrm{C}$ labeled compounds in biological systems that affords subpicomole to zeptomole ${ }^{14} \mathrm{C}$ per milligram of total carbon sensitivity with a few percent precision (15-17). Because only carboplatin bound to DNA in the form of monoadducts contains radiocarbon, as shown in Scheme 1, AMS can only detect carboplatin monoadducts from DNA samples. The measurement of Pt-DNA monoadducts by AMS from free parent compound and loss of radiocarbon from DNA due to cross-link formation allowed measurement of the rates of adduction with sensitivity and precision that may be applicable to in vivo studies.

\section{Materials and Methods}

Hazardous Materials. Caution: Carboplatin can cause birth defects and may be harmful if inhaled, absorbed through skin, or swallowed. Proper care should be taken in the handling of this material.

Chemicals. Unless otherwise noted, reagents were obtained from commercial suppliers used without further purification. ${ }^{14} \mathrm{C}$-labeled carboplatin (specific activity of $53 \mathrm{mCi} / \mathrm{mmol}$ ) was purchased from GE Healthcare.

Reaction of Carboplatin with DNA. Carboplatin solutions were prepared immediately prior to use. A mixture of $\left[{ }^{14} \mathrm{C}\right]$ carboplatin and nonlabeled carboplatin was used in order to match previously reported protocols $(6,9,11,12)$ and to minimize the usage of radiocarbon. The concentration of total carboplatin in the reaction solution was $12.4 \mu \mathrm{g} / \mathrm{mL}(33.4 \mathrm{nmol}, 33.4 \mu \mathrm{M})$, which contained $13.4 \mathrm{dpm}(96.8 \mathrm{fmol})$ of $\left[{ }^{14} \mathrm{C}\right]$ carboplatin. The carboplatin solution was incubated with salmon sperm DNA $(0.5 \mathrm{mg} / \mathrm{mL})$ (Amersham Biosciences, Piscataway, NJ) at $37{ }^{\circ} \mathrm{C}$ in $25 \mathrm{mM} \mathrm{NaCl}, 0.14 \mathrm{mM}$ EDTA, and $0.14 \mathrm{mM}$ Tris $\cdot \mathrm{HCl}, \mathrm{pH}$ 7.4. Samples of the solution were taken at a variety of time intervals up to $24 \mathrm{~h}$. DNA was isolated at $4{ }^{\circ} \mathrm{C}$ directly after each incubation, using ethanol precipitation. Conversion to graphite for AMS analysis was performed using a two-step oxidation-reduction process and analyzed for the ratio of ${ }^{14} \mathrm{C}$ to total carbon by AMS (18). All of DNA reactions were carried out in triplicate.

Dosing T24 Human Bladder Cancer Cells with $\left[{ }^{14} \mathrm{C}\right]$ Carboplatin and DNA Extraction. T24 cells were obtained from ATCC.
Cells were maintained at $37{ }^{\circ} \mathrm{C}$ in an atmosphere of $5 \% \mathrm{CO}_{2}$ in RPMI media supplemented with $10 \%$ fetal bovine serum. Exponentially growing cells were harvested by means of trypsinization, and the resulting single-cell suspension was plated onto tissue culture plates. T2 4 cells were dosed with $0.2 \mu \mathrm{M}$ of carboplatin containing $300 \mathrm{dpm}(2.16 \mathrm{pmol})$ of $\left[{ }^{14} \mathrm{C}\right]$ carboplatin in $5 \mathrm{~mL}$ of the growth media. After a 2-day incubation, the radiocarbon contents of whole cell lysis mixtures and extracted DNA were measured by AMS according to published procedures (17). All T24 dosing experiments were performed in triplicate.

\section{Results and Discussion}

Reaction of Carboplatin with Salmon Sperm DNA. To measure the kinetics of carboplatin binding to genomic DNA by AMS, radiocarbon-labeled carboplatin was incubated with salmon sperm DNA at $37{ }^{\circ} \mathrm{C}$. The fraction of drug bound to the DNA in the form of monoadducts was experimentally determined and was plotted as a function of time (Figure 1a). We observed typical kinetics of a two-step consecutive irreversible mechanism that showed a left-shifted bell shape (7). The AMS signal from the DNA corresponded only to carboplatinDNA monoadducts (see Supporting Information). The radiocarbon content of the DNA displayed an exponential decay after reaching a maximum $\mathrm{Pt}-\mathrm{DNA}$ monoadduct concentration at $\sim 4 \mathrm{~h}$ which sequestered $\sim 10 \%$ of the total radiocarbon in solution. The kinetics experiments allowed determination of the half-life of the radiocarbon-labeled monoadduct in DNA. During sample preparation, we observed that use of a G-25 sizeexclusion column to desalt the DNA, in comparison to ethanol precipitation, resulted in significant loss of radiocarbon (data not shown). This observation may result from nucleophilic groups in the G-25 packing material displacing the radiocarbonlabeled cyclobutanedicarboxylate from the Pt-DNA monoadducts. Alternatively, the ethanol precipitation may have carried out of solution a preassociation complex of aquated carboplatin electrostatically bound to the DNA (19). This possibility was minimized by quenching the platination reaction with $\mathrm{NaCl}$ prior to precipitation in order to electrostatically shield the polyphosphate DNA backbone from any positively charged aquated compound.

The concentrations of carboplatin-DNA monoadducts during the time course of the reaction allowed kinetic calculation of carboplatin binding to DNA and subsequent formation of DNA cross-links, based on the following two assumptions: (1) The five predominant forms of radiocarbon-labeled derivatives in the system are unreacted carboplatin (A), mono-aquated or mono-chlorinated carboplatin (X), mono-functional carboplatinDNA adduct (B), and free CBDCA resulting from diadduct formation (C). (2) Since the aquation or chlorination of carboplatin to form $\mathrm{X}$ is slow compared to direct binding of $\mathrm{A}$ 

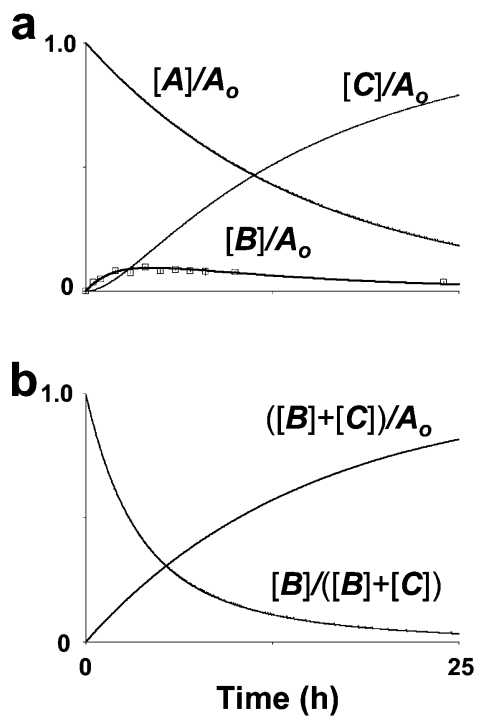

Figure 1. Reaction kinetics of carboplatin with DNA. Salmon sperm DNA $(0.5 \mathrm{mg} / \mathrm{mL})$ was incubated with carboplatin $(12.4 \mu \mathrm{g} / \mathrm{mL})$ in 25 $\mathrm{mM} \mathrm{NaCl}, 0.14 \mathrm{mM}$ EDTA, and $0.14 \mathrm{mM}$ Tris $\cdot \mathrm{HCl}, \mathrm{pH}$ 7.4. DNA isolation was performed at $4{ }^{\circ} \mathrm{C}$ by ethanol precipitation (see Supporting Information). The radiocarbon measured by AMS due to carboplatinDNA monoadducts as a fraction of the total radiocarbon is represented by the symbol $\square$. The curves were plotted using the equations discussed in the text with $k_{1}=1.88 \times 10^{-5} \mathrm{~s}^{-1}$ and $k_{2}=1.47 \times 10^{-4} \mathrm{~s}^{-1}$. A represents unreacted carboplatin, B is the carboplatin-DNA monoadduct, and $\mathrm{C}$ is the free CBDCA. (a) The fraction of radiocarbon in solution due to carboplatin, $\mathrm{Pt}-\mathrm{DNA}$ monoadducts, and CBDCA over time is represented by $[\mathrm{A}] / A_{\mathrm{o}},[\mathrm{B}] / A_{\mathrm{o}}$, and $[\mathrm{C}] / A_{0}$, respectively. (b) The fraction of the total platinum bound to DNA due to monoadducts and the fraction of platinum in solution bound to DNA is represented by $[\mathrm{B}] /([\mathrm{B}]+[\mathrm{C}])$ and $([\mathrm{B}]+[\mathrm{C}]) / A_{\mathrm{o}}$, respectively.

to DNA, the concentration of $\mathrm{X}$ can be ignored in terms of kinetic considerations leading to an $\mathrm{A} \rightarrow \mathrm{B} \rightarrow \mathrm{C}$ reaction scheme $(6,7)$.

Therefore, the concentrations of $\mathrm{A}, \mathrm{B}$, and $\mathrm{C}$ as a function of time $(t)$ are given by eqs $(1-3)$,

$$
\begin{gathered}
{[\mathrm{A}]=A_{\mathrm{o}} \mathrm{e}^{-k_{1} t}} \\
{[\mathrm{~B}]=k_{1} A_{\mathrm{o}}\left[\left(\mathrm{e}^{-k_{1} t}-\mathrm{e}^{-k_{2} t}\right) /\left(k_{2}-k_{1}\right)\right]} \\
{[\mathrm{C}]=A_{\mathrm{o}}-[\mathrm{A}]-[\mathrm{B}]=A_{\mathrm{o}}-A_{\mathrm{o}}\left[\left(k_{2} \mathrm{e}^{-k_{1} t}-k_{1} \mathrm{e}^{-k_{2} t}\right) /\right.} \\
\left.\left(k_{2}-k_{1}\right)\right]
\end{gathered}
$$

where $A_{\mathrm{o}}$ is the initial concentration of $\mathrm{A}$. The functions $[\mathrm{A}] / A_{\mathrm{o}}$, $[\mathrm{B}] / A_{\mathrm{o}}$, and $[\mathrm{C}] / A_{\mathrm{o}}$ can readily be manipulated mathematically at each time point from these equations if the two rate constants $k_{1}$ and $k_{2}$ are known. The time at which [B] reaches its maximum value can be determined by setting $\mathrm{d}[\mathrm{B}] / \mathrm{d} t=0$; the result is $t_{\mathrm{B}}{ }^{\max }=\left(k_{1}-k_{2}\right)^{-1} \times \ln \left(k_{1} / k_{2}\right)$.

This is the first report of direct experimental determination of $k_{1}$ and $k_{2}$ using radiolabeled carboplatin and genomic DNA. The data indicate that the most significant difference in rates between cisplatin and carboplatin is in the DNA binding step. Two consecutive pseudo-first-order rate constants were fitted to the experimental data according to eq 2 . The rate constants obtained were $k_{1}=(1.88 \pm 0.30) \times 10^{-5} \mathrm{~s}^{-1}$ and $k_{2}=(1.47 \pm$ $0.26) \times 10^{-4} \mathrm{~s}^{-1}$, respectively. These rate constants indicate that direct nucleophilic attack by nucleotides on carboplatin leads to $\mathrm{Pt}-\mathrm{DNA}$ monoadduct formation and that this ring-opening of carboplatin with DNA is a rate-limiting step in Pt-DNA adduction. In the analogous cisplatin reaction with genomic DNA, the limiting step is conversion of the parent compound to the monoaquated highly reactive intermediate $(k=1.02 \times$ $\left.10^{-4} \mathrm{~s}^{-1}\right)$, and the resulting compound rapidly reacts with DNA to form monoadducts $\left(k=1.96 \times 10^{-3} \mathrm{~s}^{-1}\right)$ (20). The corresponding DNA binding step with carboplatin $\left(k_{1}\right.$ in our study) is 100 -fold slower, which may explain the lower toxicity of carboplatin. This rate constant $k_{1}$ indicates a minimal or negligible concentration of preassociated aquated carboplatin, since the decay of the parent compound in solution is orders of magnitude slower than Pt-DNA adduction. After the DNA binding step, the overall monoadduct-to-diadduct conversion occurs at a similar rate for both carboplatin and the literature value for cisplatin. The rate constants $k_{1}$ and $k_{2}$ in this study were approximately 4-fold higher than those reported for binding of carboplatin to dGMP in an NMR study (7). It is not clear why $k_{1}$ in our study is faster than that for carboplatin binding to dGMP. However, the faster rate of $k_{2}$ in our study is probably due to the entropic advantage of unimolecular reaction of carboplatin monoadducts with DNA to form diadducts compared to binding of the compound to free nucleotides in solution. ${ }^{1}$ In addition, the rates allowed determination of the time of the maximum concentration of carboplatin-DNA monoadducts $\left(4.53 \mathrm{~h}, t_{\mathrm{B}}{ }^{\max }\right)$ in the system. Figure 1a also includes calculated percentages of unbound carboplatin and free CBDCA in the reaction mixture according to eqs 1 and 3, respectively.

The total concentration of platinum bound to DNA as determined by AMS was consistent with previous studies using AAS $(6,9)$. This consistency implies that the total concentration of carboplatin bound to DNA can be determined solely by measuring the radiocarbon-labeled monoadducts over time. Figure $1 \mathrm{~b}$ also shows the fraction of monoadducts compared with the total Pt in DNA exponentially decreasing over time. This may account for the large variety of reported values for the percent DNA monoadducts compared to total platinum in DNA $(9,21,22)$, since the percentage of monoadducts strongly depends on the incubation time.

Dosing T24 Human Bladder Cancer Cells with $\left[{ }^{14} \mathrm{C}\right]-$ Carboplatin. In an effort to extend this assay to biological systems, T24 human bladder cancer cells were dosed with $\left[{ }^{14} \mathrm{C}\right]-$ carboplatin at a subpharmacological dose, ${ }^{2}$ and the total amount of radiocarbon in the cells and DNA was measured by AMS (Figure 2). The time course shown in Figure 2a shows the total radiocarbon in the cells from the influx of carboplatin from the culture media. The radiocarbon in the cells represents the sum of the parent carboplatin, carboplatin-protein monoadducts, carboplatin-DNA monoadducts, and free CBDCA. The radiocarbon content in the cells ranged from $\sim 50-400 \mathrm{amol} / 10^{6}$ cells. After a 2-day incubation, only $0.0300 \pm 0.0027 \%$ of the dosed compound accumulated in the cells and $0.00147 \pm$

${ }^{1}$ The reported rate constant of $1.3 \times 10^{-5} \mathrm{~s}^{-1}$ for the monofunctional lesion in DNA (see ref 6) stands for so-called $k_{\text {tot }}$. On the basis of its definition of $k_{1} k_{2} /\left(k_{1}+k_{2}\right), k_{\text {tot }}$ in our study was calculated to be approximately $1.67 \times 10^{-5} \mathrm{~s}^{-1}$, which is consistent with the literature value, and the overall half-life of monoadducts in DNA was $11.6 \mathrm{~h}$. The rate constants reported by Frey et al. (ref 7) were obtained from the binding study of carboplatin to dGMP, and the estimated half-life of the platinated dGMP monoadduct was more than $50 \mathrm{~h}$, representing the importance of entropic disadvantage of the reaction with dGMP compared to the analogous reaction with DNA.

${ }^{2}$ It is known that the formation of carboplatin-DNA adducts is slow compared to cisplatin with $\sim 20-230$-fold more carboplatin than cisplatin (molar dose) required to obtain equal levels of platination (see ref 9). The concentration of total carboplatin in the growth media in our study was 0.2 $\mu \mathrm{M}$, which contained $300 \mathrm{dpm}(2.16 \mathrm{pmol})$ of ${ }^{14} \mathrm{C}$-labeled compound, which is equivalent to a subpharmacological dose, considering that a patient typically receives $\sim 800 \mathrm{mg} / \mathrm{m}^{2}$ carboplatin (Wong, E., and Giandomenico, C. M. (1999) Chem. Rev. 99, 2451-2466), resulting in a maximum plasma concentration of $\sim 100 \mu \mathrm{M}$. (see ref 24 ). 

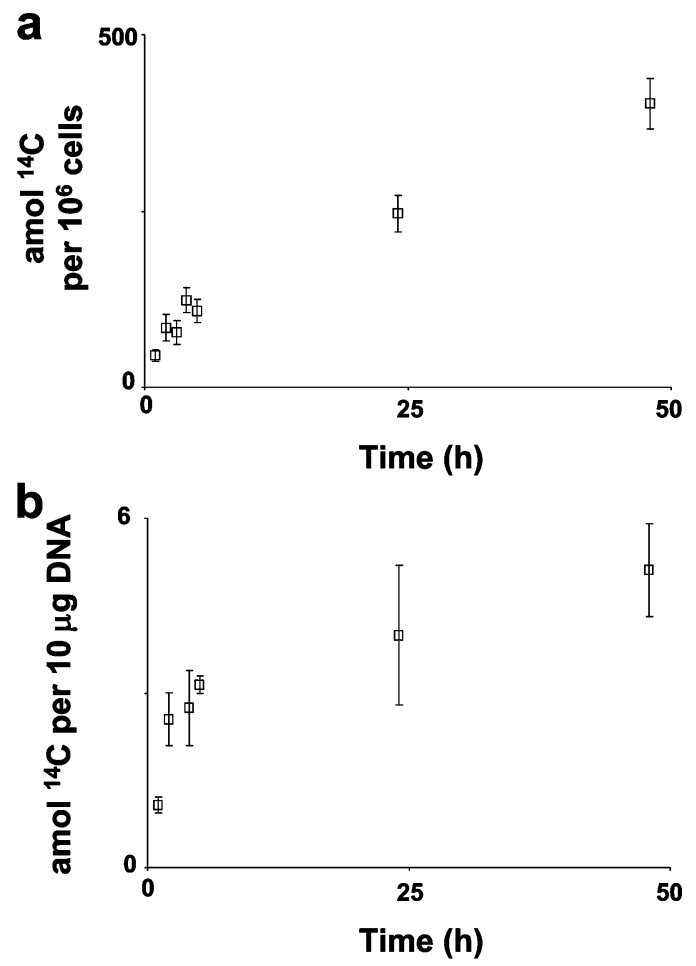

Figure 2. $\left[{ }^{14} \mathrm{C}\right]$ Carboplatin uptake into $\mathrm{T} 24$ human bladder cancer cells and binding to nuclear DNA. Cells were incubated with $0.2 \mu \mathrm{M}$ of carboplatin containing $300 \mathrm{dpm}(2.16 \mathrm{pmol})$ of ${ }^{14} \mathrm{C}$-labeled compound, followed by cell lysis and DNA extraction. Radiocarbon contents of the resulting (a) cell lysis and (b) extracted DNA were measured by AMS.

$0.00023 \%$ was localized to nuclear DNA. Therefore, approximately $4.89 \%$ of the cellular radiocarbon was found in nuclear DNA. We determined the intracellular concentration of carboplatin at $\sim 92.0 \mathrm{nM}$ after a 1-day incubation of T24 cells with $0.2 \mu \mathrm{M}$ of carboplatin based on the assumption of the volume of a single cell being $\sim 2 \mathrm{pl}(23)$. This is potentially a clinically relevant concentration for this assay, since plasma levels of carboplatin are estimated to be a maximum of $\sim 100$ $\mu \mathrm{M}$ (24). The assay sensitivity indicates that Pt-DNA concentrations can be measured in cells from patients many half-lives after a bolus dose with a radiocarbon-labeled probe in vivo. Figure $2 b$ shows that Pt-DNA monoadducts accumulate in nuclear DNA over at least 2 days, unlike the analogous experiment performed with genomic DNA (Figure 1a). This observation is apparently due to the continuous formation of carboplatin-DNA monoadducts and slower diffusion of carboplatin to nuclear DNA in cells compared to exposing pure genomic DNA to a simple-buffered solution of the drug. The radiocarbon content in the nuclear DNA ranged from $\sim 1-5$ amol/10 $\mu \mathrm{g}$ of nuclear DNA. Considering the $\sim 700$-fold dilution of the radioactive dose with unlabeled carboplatin, the calculated total monoadduct level in platinated DNA after a 2-day incubation was $3.82 \pm 0.59 \mathrm{fmol} / 10 \mu \mathrm{g}$ of DNA or approximately 15 molecules per $10^{7}$ nucleotides (see Supporting Information). It is noteworthy to compare this value with the detection limit of ICP-MS, which is $513 \mathrm{fmol} / 10 \mu \mathrm{g}$ of DNA (13), demonstrating AMS's much higher sensitivity.

While the DNA monoadducts may not have significant direct toxicity, they are the precursors to the toxic cross-links, and their repair (or lack of repair) will directly effect the concentration of cross-links. To our knowledge, repair rates of carboplatin-DNA monoadducts by excision repair have not been measured previously and, therefore, may be an important factor in differential carboplatin toxicity between resistant and sensitive cells. Reaction of the Pt-DNA monoadducts with ligands other than DNA would release CBDCA prior to cross-link formation, which would confound the assay results in a cellular system. Such interactions are not only likely to lower the toxicity of the drug, but may also be important factors in the efficacy of the treatment. Inactivation of platinum-based drugs by glutathione, metallothionein, or other sulfur-containing molecules is a known mode of drug resistance (2). The practical limitations of the assay by these competing reactions in the cellular environment will be determined in future studies.

In summary, we developed a new AMS-based assay to measure the in vitro and in vivo level of carboplatin-DNA monoadducts. We defined the kinetics of monoadduct and diadduct formation in sufficient detail to determine that individual $\mathrm{Pt}$-DNA monoadduct formation is the rate-limiting step toward the formation of toxic cross-links. This observation may explain, in part, the lower potency and toxicity of carboplatin compared to cisplatin. In T24 bladder cancer cell studies, AMS enabled detection of at least 100-fold lower concentration of carboplatin-DNA monoadducts than the limit of detection published for ICP-MS. Such high sensitivity and measurement precision may allow the method to be used for clinical applications.

Acknowledgment. We acknowledge Kurt Haack for preparation of AMS samples and Kenneth W. Turteltaub for helpful advice. This work was performed at the Research Resource for Biomedical Accelerator Mass Spectrometry, operated at University of California Lawrence Livermore National Laboratory under the auspices of the U.S. DOE contract W-7405-ENG-48 and partially supported by NIH/NCRR, Biomedical Technology Program Grant P41 RR13461, NIH Grant CA55861, and by DOE/LDRD Grant 06-LW-023.

Supporting Information Available: A detailed description of the sample preparation methods, experimental design, kinetics analysis, and cell culture protocols with figures showing raw AMS data. This material is available free of charge via the Internet at http://pubs.acs.org.

\section{References}

(1) Chaney, S. G., Campbell, S. L., Bassett, E., and Wu, Y. (2005) Recognition and processing of cisplatin- and oxaliplatin-DNA adducts Crit. Rev. Oncol. Hematol. 53, 3-11.

(2) Wang, D., and Lippard, S. J. (2005) Cellular processing of platinum anticancer drugs. Nat. Rev. Drug Discovery 4, 307-320.

(3) Fuertes, M. A., Alonso, C., and Perez, J. M. (2003) Biochemical modulation of cisplatin mechanisms of action: Enhancement of antitumor activity and circumvention of drug resistance. Chem. Rev. $103,645-662$.

(4) Kartalou, M., and Essigmann, J. M. (2001) Recognition of cisplatin adducts by cellular proteins. Mutat. Res. 478, 1-21.

(5) Jamieson, E. R., and Lippard, S. J. (1999) Structure, recognition, and processing of cisplatin-DNA adducts. Chem. Rev. 99, 2467-2498.

(6) Knox, R. J., Friedlos, F., Lydall, D. A., and Roberts, J. J. (1986) Mechanism of cytotoxicity of anticancer platinum drugs: Evidence that cis-diamminedichloroplatinum(II) and cis-diammine-(1,1-cyclobutanedicarboxylato)platinum(II) differ only in the kinetics of their interaction with DNA. Cancer Res. 46, 1972-1979.

(7) Frey, U., Ranford, J. D., and Sadler, P. J. (1993) Ring-opening reactions of the anticancer drug carboplatin: NMR characterization of cis-[Pt$\left.\left(\mathrm{NH}_{3}\right)_{2}(\mathrm{CBDCA}-\mathrm{O})\left(5^{\prime}-\mathrm{GMP}-\mathrm{N} 7\right)\right]$ in solution. Inorg. Chem. 32, 13331340.

(8) Canovese, L., Cattalini, L., Chessa, G., and Tobe, M. L. (1988) Kinetics of the displacement of cyclobutane-1,1-dicarboxylate from diammine(cyclobutane-1,1-dicarboxylato)platinum(II) in aqueous solution. $J$. Chem. Soc., Dalton Trans. 8, 2135-2140.

(9) Blommaert, F. A., van Dijk-Knijnenburg, H. C. M., Dijt, F. J., den Engelse, L., Baan, R. A., Berends, F., and Fichtinger-Schepmam, A. M. J. (1995) Formation of DNA adducts by the anticancer drug carboplatin: Different nucleotide sequence preferences in vitro and in cells. Biochemistry 34, 8474-8480. 
(10) Fichtinger-Schepmam, A. M. J., van Dijk-Knijnenburg, H. C. M., Dijt, F. J., van der Velde-Visser, S. D., Berends, F., and Baan, R. A. (1995) Effects of thiourea and ammonium bicarbonate on the formation and stability of bifunctional cisplatin-DNA adducts: Consequences for the accurate quantification of adducts in (cellular) DNA. J. Inorg. Biochem. 58, 177-191.

(11) Fichtinger-Schepmam, A. M. J., van der Veer, J. L., den Hartog, J. H. J., Lohman, P. H. M., and Reedijk, J. (1985) Adducts of the antitumor drug cis-diamminedichloroplatinum(II) with DNA: Formation, identification and quantification. Biochemistry 24, 707-713.

(12) Eastman, A. (1983) Characterization of the adducts produced in DNA by $c i s$-diamminedichloroplatinum(II) and cis-dichloro(ethylenediamine)platinum(II). Biochemistry 22, 3927-3933.

(13) Yamada, K., Kato, N., Takagi, A., Koi, M., and Hemmi, H. (2005) One-milliliter wet-digestion for inductively coupled plasma mass spectrometry (ICP-MS): determination of platinum-DNA adducts in cells treated with platinum(II) complexes. Anal. Bioanal. Chem. 382 , $1702-1707$

(14) McGurk, C. J., McHugh, P. J., Tilby, M. J., Grimaldi, K. A., and Hartley, J. A. (2001) Measurement of covalent drug-DNA interactions at the nucleotide level in cells at pharmacologically relevant doses. Methods Enzymol. 340, 358-376.

(15) Vogel, J. S. (2005) Accelerator mass spectrometry for quantitative in vivo tracing. BioTechniques 38, 13-17.

(16) Lappin, G., and Garner, R. C. (2003) Big physics, small dosed: The use of AMS and PET in human microdosing of development drugs. Nat. Rev. Drug Discovery 2, 233-240.

(17) Hah, S. S., Kim, H. M., Sumbad, R. A., and Henderson, P. T. (2005) Hydantoin derivative formation from oxidation of 7,8-dihydro-8-oxo- $2^{\prime}$-deoxyguanosine (8-oxodG) and incorporation of ${ }^{14} \mathrm{C}$-labeled 8-oxodG into the DNA of human breast cancer cells. Bioorg. Med. Chem Lett. 15, 3627-3631.

(18) Dingley, K. H., Ubick, E. A., Vogel, J. S., and Haack, K. W. (2005) DNA isolation and sample preparation for quantitation of adduct levels by accelerator mass spectrometry. Methods Mol. Biol. 291, 21-27.

(19) Elmroth, S. K. C., and Lippard, S. J. (1995) Surface and electrostatic contributions to DNA-promoted reactions of platinum(II) complexes with short oligonucleotides: A kinetic study. Inorg. Chem. 34, 52345243.

(20) Bancroft, D. P., Lepre, C. A., and Lippard, S. J. (1990) ${ }^{195}$ Pt NMR kinetic and mechanistic studies of cis- and trans-diamminedichloroplatinum(II) binding to DNA. J. Am. Chem. Soc. 112, 6860-6871.

(21) Page, J. D., Husain, I., Sancar, A., and Chaney, S. G. (1990) Effect of the diaminocyclohexane carrier ligand on platinum adduct formation, repair, and lethality. Biochemistry 29, 1016-1024.

(22) Eastman, A. (1987) The formation, isolation and characterization of DNA adducts produced by anticancer platinum complexes. Pharmacol. Ther. 34, 155-166.

(23) Ghezzi, A., Aceto, M., Cassino, C., Gabano, E., and Osella, D. (2004) Uptake of antitumor platinum(II)-complexes by cancer cells, assayed by inductively coupled plasma mass spectrometry (ICP-MS). J. Inorg. Biochem. 98, 73-78.

(24) Jacobs, S. S., Fox, E., Dennie, C., Morgan, L. B., McCully, C. L. and Balis, F. M. (2005) Plasma and cerebrospinal fluid pharmacokinetics of intravenous oxaliplatin, cisplatin, and carboplatin in nonhuman primates. Clin. Cancer Res. 11, 1669-1674. 